\title{
URGENSI PENERAPAN PENDIDIKAN AKUNTANSI BERBASIS AKUNTANSI SOSIAL DAN LINGKUNGAN
}

\author{
Anisa Kusumawardani \\ dinar.damar12@gmail.com \\ Irwansyah \\ Ledy Setiawati \\ Yoremia Lestari Ginting \\ Fibriyani Nur Khairin \\ Fakultas Ekonomi dan Bisnis Universitas Mulawarman
}

\begin{abstract}
This study aimed to identified the competencies of accountants needed by stakeholders of Higher Education in relation to social and environmental accounting. Accountants play a vital role in the process of preparing and reporting businesses, from financial reporting to non-financial reporting such as sustainability reports. Globally, there is an increasing trend of sustainability reporting; thus providing the impetus for preparing accounting students in social and environmental accounting issues. Therefore, social and environmental accounting education becomes relevant in college. Stakeholder theory and professional sustainability competence model are analytical tools to interpret the needs of college graduates who have competence in accounting profession. The data used in this study was the result of the interview with the informants who are prepared sustainability report. The urgency of applying social and environmental accounting education was reflected in the results which illustrated that none of the implementers of sustainability reporting was an accountant; whereas, institutions required implementers who have competencies of social and environmental accounting. The required competencies consist of functional competence, personal/behavioral competence, knowledge/cognitive competence, and value/ethics competence. This research contributes to the universities to know the specific sustainability competencies so that it can become a reference in curriculum of accounting education.
\end{abstract}

Key words: social and environmental accounting, competencies, accounting education, sustainability reporting, stakeholder theory

\begin{abstract}
ABSTRAK
Penelitian ini bertujuan untuk mengidentifikasi kompetensi akuntan yang dibutuhkan oleh stakeholders perguruan tinggi terkait bidang akuntansi sosial dan lingkungan. Akuntan sangat berperan dalam proses penyusunan dan pelaporan bisnis, mulai dari pelaporan keuangan hingga pelaporan nonkeuangan seperti laporan keberlanjutan. Secara global terjadi peningkatan tren pelaporan keberlanjutan, hal ini memberikan dorongan untuk mempersiapkan mahasiswa akuntansi dalam masalah akuntansi sosial dan lingkungan maka pendidikan akuntansi sosial dan lingkungan menjadi relevan di perguruan tinggi. Teori stakeholder dan model kompetensi keberlanjutan profesional sebagai alat analisis untuk memaknai kebutuhan perusahaan sebagai pengguna lulusan perguruan tinggi akan kompetensi profesi akuntan. Data berupa hasil interview dengan para informan yang merupakan pelaku penyusunan laporan keberlanjutan. Urgensi penerapan pendidikan akuntansi sosial dan lingkungan tercermin dari hasil penelitian yang menggambarkan tidak seorangpun pelaksana pelaporan keberlanjutan di institusi adalah seorang akuntan, padahal institusi memerlukan pelaksana yang memiliki kompetensi di bidang akuntansi sosial dan lingkungan. Kompetensi yang dibutuhkan tersebut terdiri dari kompetensi fungsional, kompetensi personal/perilaku, kompetensi pengetahuan/kognitif, dan kompetensi nilai/etika. Sehingga penelitian ini berkontribusi bagi perguruan tinggi untuk mengetahui kompetensi keberlanjutan secara spesifik sehingga dapat menjadi acuan dalam melakukan peninjauan kurikulum pendidikan akuntansi.
\end{abstract}


Kata kunci: akuntansi sosial dan lingkungan, kompetensi, pendidikan akuntansi, pelaporan keberlanjutan, teori stakeholder

\section{PENDAHULUAN}

Isu keberlanjutan yang merebak belakangan ini berdampak pula pada dunia akuntansi. Ketika sebelumnya yang menjadi primadona hanyalah pelaporan keuangan tahunan perusahaan saja, namun sekarang telah ditambah lagi dengan hadirnya laporan keberlanjutan sebagai respon atas isu tersebut, maka perkembangan dalam laporan keberlanjutan menjadi bagian dari masa depan pelaporan dalam akuntansi. Sehingga hal ini pun menjadi urgensi bagi mahasiswa bisnis (termasuk di bidang akuntansi) untuk memiliki wawasan tentang pelaporan keberlanjutan tersebut.

Pada tahun 2014, Association of Chartered Certified Accountants (ACCA) yang bekerja sama dengan Accounting for Sustainability melakukan studi tentang pandangan siswa mengenai isu keberlanjutan. Sebanyak $87 \%$ persen siswa dari 126 negara yakin bahwa profesi akuntan perlu memberi lebih banyak wawasan terkait pengambilan keputusan tentang keberlanjutan; 79\% setuju bahwa masalah keberlanjutan akan menjadi sangat penting dalam 10 tahun ke depan; $74 \%$ setuju bahwa dampak lingkungan terhadap organisasi akan menjadi fokus yang lebih besar bagi profesi akuntansi; dan $54 \%$ ingin terlibat dalam mengintegrasikan isu keberlanjutan ke dalam bisnis. Kondisi ini semestinya menjadi pemicu bagi institusi pendidikan akuntansi untuk semakin meningkatkan kesadaran akan pentingnya pengetahuan terkait isu tersebut diberikan kepada mahasiswa dalam proses pembelajarannya.

Laporan keberlanjutan mampu meningkatkan daya saing perusahaan karena organisasi dengan praktik keberlanjutan yang baik cenderung menjadi pelaku bisnis yang lebih baik (Rassart, 2014), disamping itu seiring meningkatnya permintaan stakeholders perusahaan atas pengungkapan data non-keuangan mendorong semakin banyak organisasi mengintegrasikan konsep keberlanjutan ke dalam strategi bisnis mereka.
Peran akuntan menjadi tidak terbatas pada pelaporan keuangan saja tetapi berkembang untuk menyediakan layanan pelaporan dan asurans keberlanjutan.

Fenomena inilah yang menciptakan peluang dan tantangan tersendiri bagi akuntan dan menjadi tugas unik bagi akuntan untuk mengembangkan perusahaan sesuai harapan stakeholders, sehingga dalam hal ini semakin dibutuhkan akuntan yang memiliki kompetensi di bidang akuntansi sosial dan lingkungan. Akuntan perlu mengetahui bagaimana mengukur dan melaporkan kegiatan keberlanjutan (Astuti, 2012). Dalam upaya untuk terus mendahului permintaan akan kompetensi pelaporan keberlanjutan ini, beberapa universitas diAmerika Serikat sekarang telah menawarkan program yang didedikasikan untuk akuntansi keberlanjutan. Lebih dari 900 universitas dengan program akuntansi sarjana atau pascasarjana, hanya 17 yang memiliki program perkuliahan yang sepenuhnya ditujukan untuk keberlanjutan. Minimnya penyelenggara program akuntansi keberlanjutan, kurangnya buku teks dan materi terkait akuntansi keberlanjutan (Wong et al., 2016) menyebabkan kurang berkembangnya akuntansi keberlanjutan. Padahal Akuntansi sosial dan lingkungan menarik untuk di pelajari lebih mendalam dan kritis karena bersifat interdisipliner, yang artinya dapat dikaji dari berbagai keilmuan seperti teori politik, teori sosial, teori manajemen, ekonomi, geografi, hukum, filsafat, dan ekologi (Milne, 2001).

Penyediaan sumberdaya yang memiliki kompetensi di bidang akuntansi keberlanjutan mempengaruhi eksistensi sebuah institusi pendidikan, terutama yang posisinya berada dekat area beroperasinya perusahaan yang berhubungan langsung dengan kegiatan eksploitasi alam. Eksistensi perguruan tinggi ini dapat dianalisis melalui hubungan stakeholders sebab baik stakeholders internal dan eksternal dapat memengaruhi strategi, 
tujuan, kualitas pengajaran dan aktivitas perguruan tinggi (Kettunen, 2015). Permintaan stakeholders berdampak pada perguruan tinggi dan bila persyaratan stakehoders berubah maka perguruan tinggi perlu untuk mengevaluasi umpan balik dan menentukan tujuannya serta memperbaiki prosesnya dalam memenuhi kebutuhan stakeholdersnya. Dengan demikian perguruan tinggi lebih berorientasi kebutuhan pasar dan bertanggung jawab kepada stakeholdersnya.

Dewasa ini sangat jelas tergambar adanya unsur market signal dalam hal perkembangan kebutuhan stakeholders terkait penyajian informasi mengenai pertanggungjawaban sosial dan lingkungan perusahaan, sehingga untuk memenuhi kebutuhan tersebut lulusan sarjana akuntansi sudah seharusnya memiliki peningkatan kompetensi yang sesuai dengan perkembangan akuntansi sosial dan lingkungan. Kesadaran dan keterlibatan institusi pendidikan tinggi dengan isu-isu sosial dan lingkungan tampak pada komitmen untuk menanamkan nilainilai kepada mahasiswa yang berkaitan dengan etika, keberlanjutan dan tanggung jawab sosial untuk meningkatkan kompetensi mahasiswa dan akuntan masa depan.

Penelitian ini dilakukan atas dasar perhatian yang ditujukan pada pendidikan akuntansi di Indonesia untuk menanggapi perkembangan kebutuhan kompetensi akuntan (khususnya bidang akuntansi sosial dan lingkungan) di masa mendatang. Motivasi penelitian ini juga didasarkan dari fakta bahwa Indonesia merupakan negara yang kaya akan Sumber Daya Alam, dan sektor migas menjadi salah satu yang terbesar. Kekayaan tersebut terutama terletak pada area yang menjadi posisi situs penelitian ini dilakukan yakni di Kalimantan Timur. Perekonomian Kalimantan didominasi oleh sektor migas dan pertambangan tetap menjadi sektor unggulan di Kalimantan Timur (Pratiwi dan Kuncoro 2017; Kuncoro dan Idris 2010). Selain migas, pertambangan (batubara) dan kelapa sawit juga merupakan kegiatan ekonomi unggulan lainnya. Secara hukum perusahaan yang bergerak pada industri ini terikat dengan UU Perseroan Terbatas No. 40/2007 mewajibkan perusahaan untuk melakukan tanggung jawab sosial dan lingkungan (TJSL), dengan harapan perusahaan dapat berperan serta dalam pembangunan ekonomi berkelanjutan guna meningkatkan kualitas kehidupan dan lingkungan yang bermanfaat. Sejalan dengan penelitian Kusumawardani et al. (2017) menemukan bahwa perusahaan yang terkait dengan industri SDA, melalui pendekatan institusional, melaksanakan pelaporan keberlanjutan institusinya untuk memenuhi regulasi yang terkait dengan bidang industri tersebut.

Terkait dengan penyedia pendidikan akuntansi (khususnya akuntansi sosial dan lingkungan) merupakan hal yang menarik dalam konteks stakeholders dunia pendidikan karena memiliki keunikan dimana perguruan tinggi tentu saja berbeda dari perusahaan. Perguruan tinggi (baik swasta maupun negeri) memiliki keunikan di tingkat hierarki status dan tata kelola yang berbeda, memiliki misi normatif, juga mempertahankan standar akademik dan kebebasan akademik yang tinggi (Lange, 2013) sehingga tujuan penelitian ini adalah untuk mengidentifikasi tentang bagaimana kompetensi akuntan yang dibutuhkan oleh stakeholders perguruan tinggi terkait bidang akuntansi sosial dan lingkungan. Identifikasi kebutuhan pemang$\mathrm{ku}$ kepentingan tersebut diharapkan berkontribusi bagi perguruan tinggi sehingga dapat menyiapkan sarana untuk mencapai kebutuhan tersebut dengan tepat, dan sekaligus membangun keunggulan kompetitif bagi institusi itu sendiri.

\section{TINJAUAN TEORETIS}

\section{Akuntansi Sosial dan Lingkungan}

Akuntansi sosial dan lingkungan telah lama menjadi perhatian dalam perkembangan ilmu akuntansi. Perkembangan tersebut diungkapkan Astuti (2009) dimulai sekitar pertengahan tahun 1990 dimana Internasional Accounting Standars Committee (IASC) mengembangkan konsep mengenai akuntansi lingkungan dan audit hak asasi 
manusia. Maka ketika gerakan peduli terhadap lingkungan mulai mendapat perhatian masyarakat, akuntansi berbenah diri agar siap menginternalisasi berbagai eksternalitas (Astuti, 2012; Kusumaningtias, 2013). Setelah itu maka terjadilah perubahan dalam standar industri dan akuntansi lingkungan mulai berkembang serta auditor profesional juga mulai mengeluarkan prinsip-prinsip tentang audit lingkungan.

Akuntansi kemudian dianggap penting karena perusahaan perlu menyampaikan informasi mengenai aktivitas sosial dan perlindungan terhadap lingkungan kepada stakeholders perusahaan. Disebutkan juga oleh Rajafi dan Irianto (2007) bahwa yang menjadi faktor pendorong munculnya akuntansi lingkungan ini ialah adanya pergeseran paradigma yang dikenal dengan The Human Exeptionalism Paradigm menuju The Environment Paradigm. Akuntansi sosial dan lingkungan ini sering juga disebut dengan istilah akuntansi hijau (green accounting), environmental accounting atau akuntansi keberlanjutan, namun ada juga literatur terdahulu yang memberikan makna berbeda terkait istilah-istilah tersebut. Dalam artikelnya Cooper (1992) menjelaskan istilah green accounting sebagai berikut:

"The introduction of "green accounting", however well thoughtout, will, under the present phallogocentric system of accounting, do nothing to avert today's environmental crisis. In fact, it could make matters even worse"

Istilah lainnya yakni akuntansi keberlanjutan didefinisikan oleh Polejewski (2011) sebagai sebuah sistem akuntansi yang dirancang untuk mempromosikan strategi keberlanjutan dan sebagai perpanjangan atau modifikasi terhadap akuntansi keuangan, akuntansi biaya atau akuntansi manajemen.

Kemudian dalam hal pelaksanaannya, green accounting sangatlah bergantung kepada karakteristik perusahaan di dalam memahami permasalahan lingkungan hidup. Pemahaman mengenai permasalahan lingkungan hidup tersebut akan mengarahkan perusahaan di dalam kebijakannya terutama terkait dengan keselamatan lingkungan hidup (Santoso, 2012). Sehingga tujuan dari hadirnya akuntansi lingkungan dan sosial ini adalah untuk menyediakan informasi biaya lingkungan dan sosial yang relevan bagi pihak-pihak yang memerlukan, sekaligus sebagai alat komunikasi antar perusahaan dengan masyarakat.

Tujuan ini dapat ditunjukkan dalam Gambar 1 di bawah ini terkait hubungan perusahaan dan masyarakat yang dijembatani oleh fungsi informasi dari akuntansi lingkungan, dan untuk ukuran keberhasilan dari implementasi akuntansi ini bukan saja tergantung pada ketepatan menggolongkan semua biaya yang dibentuk perusahaan tetapi terletak pada kemampuan dan keakuratan data akuntansi dalam menekan dampak lingkungan yang ditimbulkan dari aktivitas perusahaan (Santoso, 2012).

\section{Teori Stakeholder}

Teori stakeholder memberikan suatu pandangan pentingnya pengelola perusahaan untuk menyeimbangkan berbagai klaim yang bertentangan dari para pemangku kepentingan terhadap aktivitas yang dilakukan perusahaan. Dill dalam Solihin (2009) menekankan pentingnya memperhitungkan peran yang dapat dilakukan pemangku kepentingan dalam mempengaruhi keputusan yang dibuat oleh manajer perusahaan. Gray et al. dalam (Januarti dan Apriyanti, 2005) mengemukakan bahwa teori stakeholder mengasumsikan bahwa eksistensi suatu perusahaan memerlukan dukungan stakeholder, sehingga aktivitas perusahaan harus mempertimbangkan persetujuan dari stakeholder. Semakin kuat stakeholder, maka perusahaan harus semakin beradaptasi dengan stakeholder. Pengungkapan sosial kemudian dipandang sebagai dialog antara perusahaan dengan stakeholder. Jika dihubungkan dengan stakeholder dalam konteks perguruan tinggi terdiri dari mahasiswa (dan calon mahasiswa), pemerintah, dosen, karyawan, peneliti, organisasi non pemerintah, korporasi bisnis lokal, 


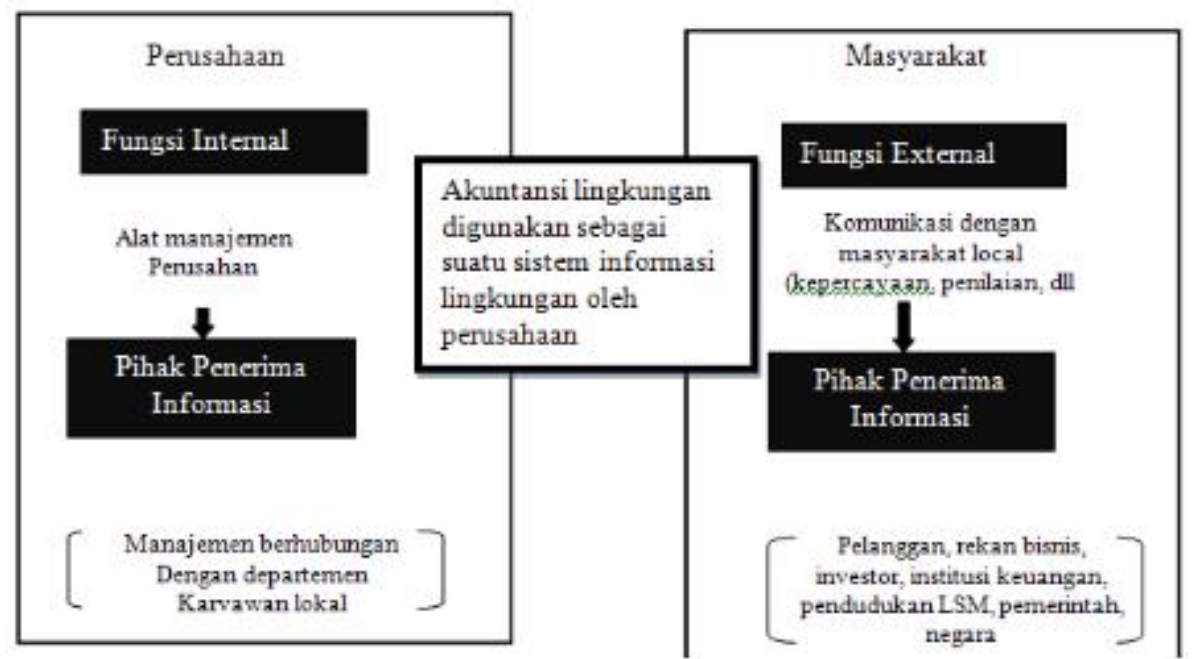

Sumber: Ministry of The Environmental Japan, 2005, Environmental Accounting Guidelines (Santoso, 2012)

Gambar 1

Hubungan antar Perusahaan dengan Masyarakat dan Akuntansi Lingkungan

asosiasi profesional, universitas pesaing, alumni, keluarga mahasiswa, dan media (Lange, 2013; Mainardes et al., 2010).

Secara spesifik, Kettunen (2015) menyatakan masyarakat dan pihak swasta adalah kelompok sasaran/target out put pendidikan tinggi dan pelanggan/customer dari institusi pendidikan tinggi. (Banerjee, 2004; Çalıskan, 2014; Wymer dan RundleThiele, 2017) menegaskan kembali bahwa sebagai pendidik/dosen, tujuan tertinggi adalah untuk membantu siswa memperoleh keterampilan yang dibutuhkan agar dapat berpartisipasi dalam perdebatan yang sedang berlangsung di masyarakat, hal ini yang mendorong banyak sekolah bisnis telah menjadikan pentingnya pemenuhan kebutuhan stakeholders utama mereka, tidak hanya untuk memenuhi kebutuhan bisnis akan manajer yang terlatih namun juga tanggung jawab kepada stakeholders yang lebih luas yakni menjadi anggota masyarakat yang bertanggung jawab.

Akuntan, Pelaporan Keberlanjutan dan Kontribusi Perguruan Tinggi

Akuntansi merupakan sistem pengukuran penting aktivitas bisnis. Sebagai produk akuntansi yang paling nyata, laporan keuangan memberikan cara yang paling penting bagi perusahaan untuk mengkomunikasikan hasil operasi kepada para pemangku kepentingannya. Peran akuntansi semakin penting, terutama saat ini ketika meningkatnya kebutuhan informasi akan masalah-masalah sosial dan lingkungan sehingga ada tekanan yang juga meningkat untuk mengintegrasikan isu keberlanjutan ke dalam sistem pengambilan keputusan perusahaan untuk mengarahkan perilaku bisnis menuju pembangunan berkelanjutan (Çalıskan, 2014).

Terkait dengan isu keberlanjutan ini, Sustainability Accounting Standards Board (SASB) menginisiasi sebuah kerangka konseptual yang didasarkan pada lima dimensi keberlanjutan yang tidak terlepas dari kepentingan stakeholder didalamnya. Dimensi-dimensi yang menyusun kerangka keberlanjutan tersebut antara lain:

Pertama, Lingkungan Hidup. Dimensi ini mencakup dampak lingkungan, baik melalui penggunaan sumber daya alam yang tidak terbarukan atau melalui pelepasan bahan berbahaya ke lingkungan yang dapat mengakibatkan dampak terhadap kondisi keuangan atau kinerja operasi perusahaan.

Kedua, Sosial. Dimensi ini berkaitan dengan harapan bahwa sebuah bisnis akan memberi kontribusi pada masyarakat 
sebagai imbalan sosial, sehingga penting untuk mengelola hubungan dengan stakeholders, seperti pelanggan, masyarakat lokal, masyarakat umum, dan pemerintah. Ini mencakup isu-isu yang berkaitan dengan hak asasi manusia, perlindungan atas kaum yang lemah, pengembangan ekonomi lokal, kualitas produk dan layanan, keterjangkauan, praktik bisnis yang bertanggung jawab dalam pemasaran, dan privasi pelanggan.

Ketiga, Sumber daya manusia. Dimensi ini membahas pengelolaan sumber daya manusia perusahaan seperti karyawan, sebagai aset utama untuk memberikan nilai perusahaan dalam jangka panjang. Ini mencakup isu-isu yang mempengaruhi produktivitas karyawan, pengelolaan hubungan kerja, pengelolaan kesehatan dan keselamatan karyawan dan kemampuan menciptakan budaya keselamatan.

Keempat, Model Bisnis dan Inovasi. Dimensi ini membahas integrasi masalah lingkungan, manusia, dan sosial dalam proses penciptaan nilai perusahaan, termasuk pemulihan sumber daya dan inovasi lainnya dalam proses produksi; serta dalam inovasi produk, termasuk efisiensi.

Kelima, Kepemimpinan dan Tata Kelola. Dimensi ini melibatkan pengelolaan isuisu yang melekat pada model bisnis atau praktik umum di industri dan yang berpotensi menimbulkan konflik dengan kepentingan kelompok pemangku kepentingan yang lebih luas, dan oleh karena itu menciptakan potensi tanggung jawab, pembatasan atau penghapusan ijin untuk beroperasi. Ini termasuk kepatuhan terhadap peraturan, manajemen risiko, manajemen keselamatan, rantai pasokan dan sumber bahan baku, konflik kepentingan, perilaku anti-kompetitif, korupsi dan suap.

Sehingga, pelaporan keberlanjutan telah menjadi sebuah kebutuhan untuk pengambilan keputusan oleh para pelaku bisnis baik manajemen perusahaan maupun stakeholdersnya karena laporan tersebut merupakan elemen kunci untuk menelusuri praktik keberlanjutan perusahaan. Menurut (Sanchez, 2015) kontribusi utama akuntansi dalam keberlanjutan dapat digambarkan sebagai berikut:

1) Mengembangkan standar akuntansi keberlanjutan, dan standar pelaporan keberlanjutan baik di tingkat nasional maupun di lingkup sektoral;

2) Membangun hubungan antara nilai keuangan dan non-keuangan perusahaan;

3) Melaporkan hasil dan interaksi aktivitas perusahaan yang terkait dengan lingkungan dan sosial;

4) Membuat praktik keberlanjutan perusahaan dapat dilacak dan dikelola; dan

5) Memiliki peran dalam menginformasikan dan mendidik pihak terkait.

Institusi pendidikan tinggi, seperti juga halnya dengan dunia bisnis, menghadapi tuntutan baru dan kompleks. Para dosen/ pendidik di bidang keilmuan bisnis memainkan peran kunci dalam menumbuhkan kesadaran dan tanggung jawab sosial dan lingkungan perusahaan, misalnya dalam perkuliahan para dosen dapat memberi penekanan bahwa akuntan memiliki peran dalam pelaporan keberlanjutan sehingga para mahasiswa diharapkan lebih siap mengelola masalah sosial dan lingkungan perusahaan (Sanchez, 2015). Tantangan bagi para akademisi dan perguruan tinggi di bidang ilmu bisnis adalah mencetak pemimpin yang bertanggung jawab serta tanggap merespons isu perubahan iklim dan keberlanjutan. Oleh karena itu, para pemimpin/pengelola perguruan tinggi perlu memiliki keberanian untuk memikirkan jauh ke depan mengenai seperti apa dunia masa depan dimana mereka berkontribusi di dalamnya sehingga menuntut komitmen yang tinggi untuk menerapkan paradigma kepemimpinan yang baru dan transformasi perilaku organisasi (Adams et al., 2011).

Menurut Mathews dan Sturt (2002) generasi berikutnya dari akuntan perlu diperkenalkan ke dasar teoritis yang lebih luas. Arti luas di sini ialah mempersiapkan setiap mahasiswa untuk dapat menerima perubahan, mengembangkan keterampilan berpikir secara moral mengenai isu-isu sosial dan lingkungan, memikirkan bagaimana 
peran akuntansi dalam masyarakat, mencari kemungkinan format alternatif pelaporan, memperluas definisi kelompok pemangku kepentingan, dan mengatasi kebutuhan akan standar maupun audit pelaporan sosial dan lingkungan.

Perguruan Tinggi memiliki peran penting dalam membangun kompetensi profesional melalui kurikulum (Adams et al., 2011; O'Byrne et al., 2015). Hal itu dapat dilakukan dengan cara mengintegrasikan nilai-nilai yang melekat dalam pembangunan berkelanjutan ke dalam semua aspek pembelajaran, yang tujuannya adalah untuk mengembangkan pengetahuan, keterampilan, perspektif, dan nilai-nilai yang akan mempersiapkan mahasiswa dan komunitas kampus agar menjadi pengambil keputusan yang lebih mahir dalam masa depan yang semakin kompleks, dinamis, dan tidak pasti.

\section{Pendidikan dan Kompetensi Akuntansi sosial dan lingkungan}

Seiring dengan berkembangnya isu lingkungan global, terjadi perubahan paradigma akuntansi yang menganjurkan bahwa fokus dari proses akuntansi tidak hanya pada transaksi keuangan tetapi juga transaksi peristiwa sosial dan lingkungan. Hal ini mengandung implikasi bahwa laporan tidak hanya terbatas pada pelaporan keuangan, melainkan juga mencakup pelaporan sosial dan lingkungan. (Yarime et al., 2012) menyatakan urgensi reformasi akuntansi konvensional menuju akuntansi keberlanjutan, sebab relevan dengan realitas akuntansi saat ini. Realitas yang ada perusahaan yang membuat laporan keberlanjutan setiap tahunnya meningkat sehingga peran akuntan yang memiliki kompetensi di bidang akuntansi sosial dan lingkungan semakin diperhitungkan. Kompetensi tersebut dapat diperoleh melalui pendidikan.

Pendidikan untuk pembangunan berkelanjutan didefinisikan sebagai konsep dinamis yang memanfaatkan aspek kesadaran masyarakat, pendidikan, dan pelatihan untuk menciptakan dan meningkatkan pemahaman tentang keterkaitan antara berbagai isu pembangunan berkelanjutan, yang tujuannya adalah untuk mengembangkan pengetahuan, keterampilan, perspektif, dan nilai-nilai untuk menciptakan dan menikmati masa depan yang berkelanjutan (Lange, 2013). Dunia pendidikan, kaitannya dengan perguruan tinggi, memiliki perilaku fungsional mereka sendiri untuk melakukan perubahan, seperti mengajarkan praktik keberlanjutan sehingga secara luas mempengaruhi masyarakat (Lange, 2013). Inilah peran perguruan tinggi sebagai agen perubahan (Stephens et al., 2008); (Sharma, 2017). Stephens et al. (2008) mengusulkan bahwa sebagai agen perubahan maka perguruan tinggi dapat menyediakan model praktik berkelanjutan untuk masyarakat, mengajar mahasiswa bagaimana menangani masalah, dan melakukan practice based research. Sebagai agen perubahan, perguruan tinggi merancang kurikulum yang juga mencakup pengetahuan dan keterampilan baru untuk mempromosikan dan meningkatkan topik keberlanjutan. Sehingga proses "penambahan" sebuah kompetensi baru bagi para calon akuntan dalam institusi pendidikan terkait dengan isu sosial dan lingkungan menjadi hal yang penting untuk dipertimbangkan.

Berdasarkan SK Mendiknas No.045/ $\mathrm{u} / 2002$ kompetensi adalah seperangkat tindakan cerdas, penuh tanggung jawab yang dimiliki seseorang sebagai syarat untuk dianggap mampu oleh masyarakat dalam melaksanakan tugas-tugas di bidang pekerjaan tertentu. Lebih lanjut Mulyati (2012) mempertegas makna kompetensi sebagai bagian dari kepribadian seseorang yang cukup dalam dan bersifat sementara, oleh karenanya selain merupakan suatu penyebab, ia juga dapat digunakan untuk mempridiksi perilaku seseorang dalam berbagai situasi dan tugas kerja. Secara aktual, kompetensi dapat memprediksi kinerja seseorang karena dapat menunjukkan siapa yang lebih baik dari pada yang lain berdasarkan specific criterion atau suatu standar tertentu. Sehingga, kompetensi akuntan dapat didefinisikan 
sebagai sebuah kapabilitas dan kemampuan yang terdiri dari pengetahuan, nilainilai profesional, etika, dan sikap yang dibutuhkan untuk menjalankan profesi akuntan (Chaker dan Abdullah, 2011). Ketika seseorang memanfaatkan kemampuan untuk melakukan tugas yang diperlukan sesuai standar yang dipersyaratkan, kompetensi dianggap telah tercapai sesuai dengan definisi yang diberikan oleh IFAC (2008) kompetensi merupakan kemampuan peran kerja atau tugas yang relevan dengan standar yang dipersyaratkan.

Seorang lulusan Sarjana Akuntansi yang kelak menjalani profesi akuntan dituntut untuk selalu mengembangkan kompetensinya sejalan dengan beragam kebutuhan dan tuntutan dunia kerja, karena itu pendidikan sebagai cara meningkatkan kompetensi dapat dilakukan dengan memilih model yang tepat. $\mathrm{Ng}$ et al. (2017) merumuskan kompetensi keberlanjutan secara spesifik yang dikembangkan dari meta-kompetensi Fleming, model holistik kompetensi professional Cheetham dan Chivers, dan SECI Model Nonaka dan Takeuchi. Sehingga (Sugiyono, 2006) mengajukan kompetensi keberlanjutan secara spesifik yang terdiri dari empat komponen utama:

Pertama, Kompetensi Fungsional, yakni kemampuan untuk melakukan berbagai tugas berbasis kerja (work-based tasks) yang efektif menghasilkan hasil yang spesifik;

Kedua, Kompetensi Personal atau Perilaku, ini adalah kemampuan untuk menerapkan perilaku yang sesuai dan dapat diamati dalam situasi yang berhubungan dengan pekerjaan;

Ketiga, Kompetensi Pengetahuan atau Kognitif, merupakan kepemilikan pengetahuan berbasis kerja yang sesuai dan kemampuan untuk menerapkan ini dengan efektif

Keempat, Kompetensi Nilai atau Etika, yaitu kepemilikan nilai-nilai pribadi dan profesional yang sesuai dan kemampuan untuk membuat penilaian yang baik berdasarkan hal-hal ini dalam situasi yang berhubungan dengan pekerjaan. Keterkaitan kompetensi etis dengan nilai menekankan bahwa nilai seperti pengetahuan, tidak banyak gunanya kecuali diterapkan secara efektif. Kompetensi etis ini mengacu pada penerapan nilai-nilai yang efektif dan tepat dalam pengaturan profesional.

\section{METODE PENELITIAN}

Penelitian ini merupakan penelitian kualitatif dengan pendekatan studi kasus. Penelitian kualitatif merupakan penelitian yang mengkaji perspektif informan dengan strategi-strategi yang bersifat interaktif dan fleksibel. Penelitian kualitatif ditujukan untuk memahami fenomena-fenomena sosial dan sudut pandang informan (Sugiyono, 2006). Penelitian ini mencoba mengidentifikasi pentingnya keberadaan akuntansi sosial dan lingkungan dalam pendidikan akuntansi di perguruan tinggi. Pendekatan studi kasus sendiri digunakan untuk memperoleh gambaran beberapa aspek khusus yang perlu dipelajari secara intensif dan mendalam.

Situs penelitian ini merupakan perusahaan pertambangan yang beroperasi di Kalimantan Timur. Informasi berasal dari National Center for Sustainability Reporting (NCSR) dimana perusahaan-perusahaan tersebut telah menyusun dan melaporkan kinerja ekonomi, lingkungan dan sosial dalam Sustainability Reporting. Mengapa perusahaan pertambangan? Sebab perusahan di bidang ini termasuk bidang usaha yang mendominasi di daerah Kaltim dan terdapat kecenderungan melakukan eksploitasi alam. Perusahaan-perusahaan tersebut terikat dengan aturan UU PT serta berkewajiban melaksanakan dan melaporkan program CSR kepada pemerintah dan masyarakat, sehingga (seharusnya) membutuhkan akuntan di bidang sosial dan lingkungan dalam proses perencanaan program sampai dengan pelaporan.

Data yang dibutuhkan dalam penelitian ini berupa hasil wawancara dengan informan dari perusahaan pertambangan (khususnya) yang beroperasi di Kalimantan Timur yang terikat dengan aturan UU No.40 
Tahun 2007 tentang Perseroan Terbatas dan Perda Kaltim No.3/2013 tentang Tanggung Jawab Sosial Lingkungan Perseroan Terbatas serta Program Kemitraan dan Bina Lingku- ngan. Berikut dipaparkan secara singkat beberapa informan dari perusahaan yang dilibatkan dalam penelitian table 1 .

Tabel 1

Data Informan dalam Penelitian

\begin{tabular}{ll}
\hline \hline \multicolumn{1}{c}{ Informan } & \multicolumn{1}{c}{ Keterangan } \\
\hline Ibu N & Manager Community Empowerment, Perusahaan K \\
Bapak R & Specialist Reporting E Data Management, Perusahaan K \\
Ibu A & Community Development Head, Perusahaan I \\
Bapak G & Human Resources Head, Perusahaan I \\
Bapak S & Community empowerment, Perusahaan K \\
\hline
\end{tabular}

Sumber: diolah peneliti (2017)

Langkah berikutnya peneliti melakukan wawancara mendalam kepada informan yang terlibat langsung di bidang yang terkait penyusunan dan pelaporan kegiatan CSR perusahaan tersebut. Kemudian informasi yang diperoleh dari proses ini akan dianalisis dengan menggunakan teori stakeholder dan model kompetensi keberlanjutan profesional yang diajukan oleh (Kettunen, 2015) guna mengidentifikasi kebutuhan pengguna akan lulusan sarjana akuntansi yang berkompeten dalam bidang akuntansi sosial dan lingkungan dilihat dari sudut pandang stakeholders. Model tersebut terdiri dari empat komponen kompetensi utama yang saling berkaitan, yakni kompetensi fungsional, personal atau perilaku, pengetahuan atau kognitif dan kompetensi nilai atau etika sehingga pada akhirnya diperoleh pemetaan akan kebutuhan kompetensi sarjana akuntansi yang holistik dan nantinya dapat diserap serta bermanfaat bagi masyarakat. Tahapan teknik analisis data penelitian dapat digambarkan gambar 2 .

\section{ANALISIS DAN PEMBAHASAN \\ Pendidikan Akuntansi Sosial Dan Lingkungan: Perspektif Stakeholders Perguruan Tinggi}

Selama ini stakeholders dalam dunia bisnis dipahami sebagai semua pihak yang memiliki minat dalam aktivitas organisasi yang diberikan. Pemangku kepentingan telah dianggap sebagai organisasi, jaringan dan orang-orang pribadi yang mampu memengaruhi tujuan dan aktivitas organisasi (Kettunen, 2015) sehingga dengan mengadopsi perspektif ini justifikasi dan eksistensi lembaga pendidikan tinggi dapat dianalisis melalui hubungan pemangku kepentingannya. Pemangku kepentingan internal dan eksternal dapat memengaruhi strategi dan tujuan, kualitas pengajaran dan aktivitas lainnya, serta prosesnya dalam hubungan dengan pemangku kepentingan.

Keberhasilan lembaga pendidikan tinggi tergantung pada kemampuannya dalam pendekatan manajemen masing-masing (Mainardes et al., 2010). Ketika persyaratan (kebutuhan) pemangku kepentingan berubah maka lembaga pendidikan tinggi mengevaluasi umpan balik, menentukan tujuannya dan memperbaiki prosesnya untuk memenuhi kebutuhan mereka.

Berdasarkan hal tersebut, stakeholders perguruan tinggi yang menjadi fokus dalam penelitian ini ialah pihak swasta atau korporasi lokal di bidang pertambangan. Regulasi Bapepam dan UU No. 40 tahun 2007 tentang Perseroan Terbatas (PT) adalah regulasi yang mengatur kewajiban melaksanakan CSR dan melakukan pengungkapan tang- 
74 Ekuitas: Jurnal Ekonomi dan Keuangan - Volume 2, Nomor 1, Maret 2018 : 65 - 82

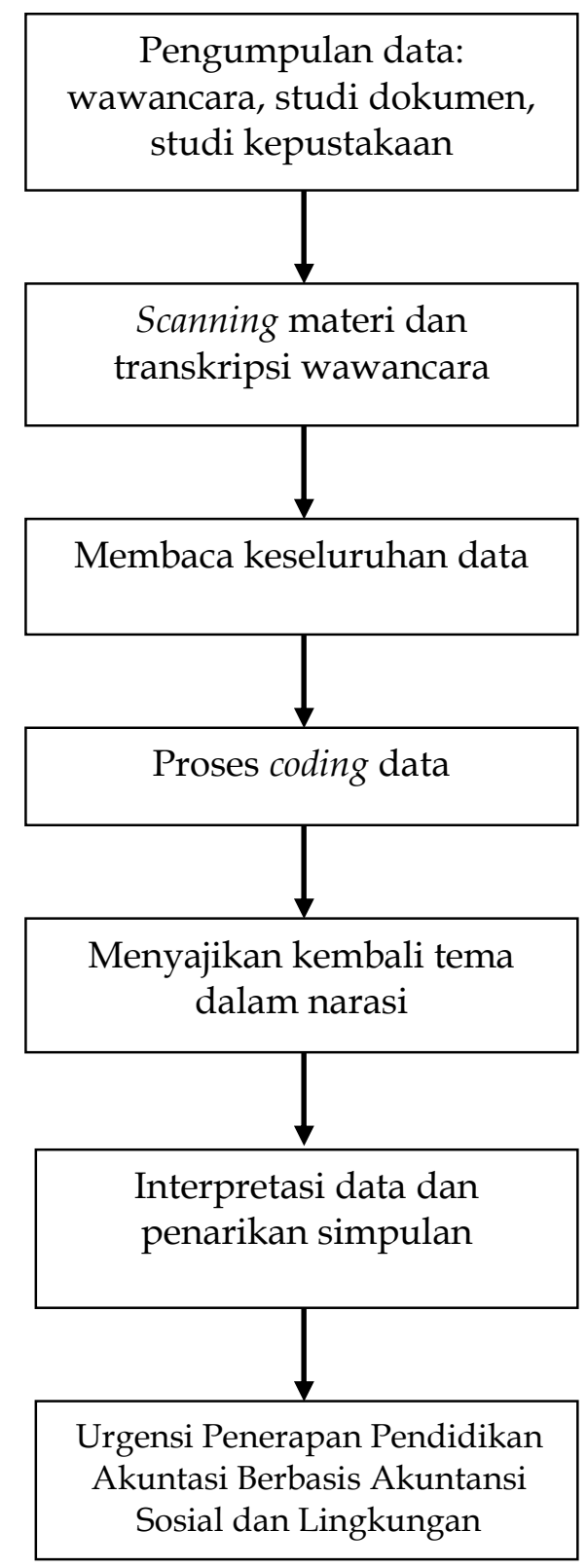

\section{Gambar 2}

Tahapan Penelitian

gung jawab sosial dan lingkungan bagi perusahaan yang bergerak di bidang sumber daya alam. Selain itu perusahaan pertambangan tersebut diatur juga dengan regulasi pemerintah lokal seperti Perda Kaltim No.3/ 2013 tentang Tanggung Jawab Sosial dan Lingkungan PT serta Program Kemitraan dan Bina Lingkungan, serta menyesuaikan kegiatan CSR perusahaan dengan agenda pemerintah setempat. Kondisi ini tersebut tergambar dari ungkapan para informan berikut:

"Implementasi CSR kami lakukan berdasarkan UU PT, Perda juga. Selain itu dari Permen. Program CSR sinkron dengan program gubernur Kaltim juga... selain itu kita juga diatur oleh forum CSR. Kita ada zona tersendiri, kita saling berbagi, sehingga tidak terjadi tumpang tindih"." (Ibu A) 
Ditegaskan pula oleh informan lainnya dari perusahaan yang berbeda:

"Salah satu mengacu pada agenda pemerintah Kutai Timur di bidang Agribisnis. Karena ini daerah baru. Itulah yang kami kerjakan bersama, dengan berbagai stra- tegi." (Ibu N)

Nampak jelas dari pengakuan tersebut bahwa pelaksanaan tanggung jawab sosial dan lingkungan maupun pelaporannya oleh perusahaan pertambangan dikarenakan adanya regulasi yang mewajibkan. Perusahaan belum menjadikan tanggung jawab sosial dan lingkungan sebagai bagian dari strategi bisnis perusahaan dan manajemen risiko. Padahal makna 'bertanggung jawab secara sosial' tidak sebatas hanya mematuhi kewajiban hukum dan undang-undang, tetapi juga dengan tanggung jawab sosial yang merupakan investasi konstan dalam sumber daya manusia atau masyarakat di mana perusahaan beroperasi (Sihombing, 2015).

Selain untuk memenuhi regulasi, praktik tanggung jawab sosial dan lingkungan dilakukan untuk mengakomodasi kepentingan stakeholders, namun karena berbagai perbedaan kepentingan maka antara perusahaan dan stakeholders-nya terjadi perbedaan paradigma mengenai dimensi tanggung jawab sosial dan lingkungan. Layaknya yang diungkapkan informan berikut tentang bagaimana mempraktikkan CSR dalam perusahaan mereka:

"Perusahaan mengalokasikan dana kurang lebih 5jt US, cash dan in kind. 5 juta dolar itu lihatnya alokasi dengan output yang sekian. Jadi indikator utamanya bukan spendingnya tetapi capaian mau ngapain aja. Ini yang perlu dipahamin, ada orang yang hanya ngelihat kok gak nyampe ya, tapi gak pernah bertanya sudah jadi apa. Ini kan bukan bagi-bagi duit." (Ibu N)

Konsep dan praktik tanggung jawab sosial dan lingkungan yang telah mereka lakukan selama ini tidak memiliki makna universal jika dilihat dari sudut pandang stakeholder perusahaan (Humphrey et al., 2017). Seperti komentar Ibu $\mathrm{N}$ yang menyatakan bahwa:
"Buyer, Pemerintah, LSM... Belum sama cara pandangnya tentang CSR..." Sehingga menumbuhkan harapan dari perusahaan akan peran dari institusi perguruan tinggi agar dapat melakukan literasi untuk meluruskan pemahaman atas CSR yang seringkali dipelesetkan menjadi "Cuma Sekedar Rupiah." Harapan tersebut diungkapkan sebagai berikut:

"Tantangan kita sebenarnya itu adalah pemahaman CSR. Ada banyak perspektif. Sesuai kepentingan masing-masing. Kedepannya adik-adik mahasiswa perlu ditanamkan pemahaman yang tepat tentang CSR. Bagaimana menjembatani? Akademisi lah yang menjembatani, sebagai yang netral." (Bapak S)

Dalam sudut pandang perusahaan, perguruan tinggi memiliki peran untuk menjembatani perbedaan paradigma tentang CSR sebab perguruan tinggi adalah pihak yang netral, bebas dari konflik kepentingan. Istilah "agen perubahan" yang digunakan oleh Stephens et al. (2008) menunjuk pada perguruan tinggi dimana berada pada posisi unik di masyarakat sebab perguruan tinggi merupakan tempat produksi pengetahuan, pengabdian, dan penyebaran pengetahuan. Perguruan tinggi memiliki potensi besar untuk memengaruhi perubahan positif dengan memberikan informasi yang tidak bias dan jelas kepada perusahaan dan stakeholdersnya seperti pemerintah dan masyarakat. Para mahasiswa sebagai calon akuntan adalah advokat (Dahle dan Neumayer, 2001) yang mempromosikan pentingnya kelestarian lingkungan termasuk pentingnya akuntansi hijau dan keterlibatan mereka dalam kelompok sosial berpotensi dalam mendorong perubahan di masyarakat (Christensen et al., 2007)

Pelaksanaan CSR dan pelaporannya ini pun tidak terlepas pada pelaksananya. Hasil penelitian ini menemukan realitas yang "tanpa akuntan," dimana dalam prosesnya di perusahaan yang menjadi pelaksana aktivitas dan pelaporan CSR ini tidak ada satupun akuntan yang terlibat. Temuan ini dikisahkan oleh informan sebagai berikut: 
"Personal CSR dari berbagai karakter pendidikan. Ada pertanian, komunikasi, IT. Intinya CSR tidak spesifik kita ahli di bidang itu." (Ibu A)

"Saya sendiri orang bahasa. Divisinya Specialist Reporting and Data Management. Di bagian ini tidak ada orang akuntansi." (Bapak R)

Fenomena ini bisa jadi menjadi sinyal bagi profesi akuntan agar semakin berbenah diri dan memperluas kompetensi yang dimilikinya, karena pelaporan kegiatan CSR yang tergambar dalam Sustainability Reporting pun tidak dapat terpisahkan dari kinerja keuangan yang dilaporkan perusahaan dalam Annual Report-nya. Masihkah akuntan mau menutup mata dan merasa bahwa aspek tanggung jawab sosial dan lingkungan bukanlah bagian dari "kehidupan" profesional mereka? CSR sendiri bukanlah kegiatan yang mudah dan murah untuk dilakukan sebuah institusi sebab membutuhkan perencanaan dan perhitungan yang matang. Oleh karena itu, yang memegang peran penting dalam hal ini adalah seorang akuntan dan akuntan harus berkompetisi lebih aktif dengan spesialis bidang lainnya yang terlibat dalam pelaporan keberlanjutan (Ascui dan Lovell, 2012; Sihombing, 2015)

Kondisi minim bahkan tidak adanya akuntan yang terlibat dalam proses pertanggungjawaban perusahaan ini bukan berarti tidak diperlukannya akuntan disana. Sebaliknya, institusi (sebagai stakeholder perguruan tinggi) membutuhkan akuntan dengan kompetensi extra untuk terlibat didalamnya, maka jika calon akuntan masa kini hanya dibekali kompetensi terkait proses penyusunan sampai dengan pelaporan keuangan saja, oleh pasar dianggap belum memenuhi kebutuhan mereka (Pratama, 2015). Perlu menjadi perhatian bagi perguruan tinggi sebagai pencetak para akuntan bahwa untuk memenuhi harapan tersebut, seorang akuntan juga diharapkan memililki kompetensi spesifik terkait laporan keberlanjutan sebagai pengungkapan tanggung jawab sosial dan lingkungan perusahaan.

\section{Kompetensi Akuntan Sosial dan Lingku- ngan}

Berkaca dari realitas kebutuhan institusi korporasi yang menjadi bagian penelitian ini, menimbulkan kesadaran akan pentingnya akuntan yang memiliki kompetensi terkait akuntansi sosial dan lingkungan selain kompetensi umum yang telah dikenal sebelumnya, sehingga perguruan tinggi yang menghasilkan sarjana akuntansi juga perlu mempertimbangkan seperti apa sebenarnya kompetensi extra yang dibutuhkan stakeholder-nya. Langkah berikutnya dalam penelitian ini adalah mengungkapkan dimensi kompetensi, terkait akuntansi sosial dan lingkungan yang diharapkan stakeholder dimiliki oleh para akuntan.

Berdasarkan hasil wawancara dengan informan diperoleh beberapa temuan yang dalam penelitian ini berupa pemetaan kebutuhan tersebut yang dianalisis menggunakan model kompetensi profesional $\mathrm{Ng}$ et al., (2017). Berikut adalah hasil analisis dan pemetaan yang memaparkan empat kompetensi keberlanjutan yang spesifik berdasar kan model Ng et al., 2017.

\section{Pertama, Kompetensi Fungsional}

Kompetensi fungsional meliputi (a) kemampuan untuk mengidentifikasi dan mengenali pendekatan dan metode pelaporan CSR/Sustainability, dan (b) pengetahuan tentang metodologi untuk penilaian risiko keberlanjutan. Kompetensi ini sesuai dengan pernyataan informan yang menjadi pelaku di bidang pelaporan akuntansi keberlanjutan, dimana kompetensi untuk mengidentifikasi informasi apa saja yang penting untuk diungkapkan dalam laporan keberlanjutan berdasarkan standar pelaporan yang menjadi acuan, seperti GRI dan ISO 26000. Acuan ataupun standar pelaporan juga akan membantu stakeholder dalam menilai kinerja perusahaan: ekonomi, lingkungan, dan sosial (Jankalova, 2016; Kaya, 2016). Selain mengidentifikasi informasi, kemampuan membaca laporan keberlanjutan menjadi kompetensi tambahan. Seperti yang dijelaskan oleh informan berikut: 
"Secara esensi CSR yang perlu untuk disampaikan di jurusan ya, sebagai dasarnya, kalo gitu acuannya yang ISO 26000 untuk memahami apa itu CSR." (Mrs.N)

Penjelasan informan tersebut mengidentifikasi pemahaman akan acuan atau standar terkait implementasi dari CSR merupakan hal yang penting untuk dimiliki akuntan. Berikut juga pemaparan senada akan perlunya penguasaan dan pemahaman atas guidance tersebut:

"Kebetulan enaknya di perusahaan ini, kita sudah ada kontributor di tiap departemen dan divisi. Sebagian besar dari mereka sudah mendapatkan pelatihan tentang GRI ini. Sebagian besar sudah dapat training mengerti GRI ini, sebagian besar mengerti apa yang harus disajikan." (Bapak R)

Selain itu proses penyusunan laporan keberlanjutan yang umumnya menggunakan GRI Guidance menjadi sebuah keharusan bagi akuntan terkait penguasaannya:

"Bagi yang menulis (penyusun laporanred), di tempat kami saya gak tahu udah berapa anggota, jadi kita semua dikursusin untuk menulis report dengan Global Reporting Initiative. Jadi kita belajar bagaimana menyusun itu (laporan keberlanjutan-red)". (Ibu N)

Kompetensi ini menurut Manoliadis (2009); Osagie et al. (2016) mengarah pada bagaimana memahami CSR, Standar CSR, dan regulasi CSR bahwa akuntan dan siapa saja yang berada dalam divisi Keberlanjutan harus memahami bagaimana menerapkan dan mengatasi peraturan baik dalam lingkup industri, nasional dan internasional. Selain aspek regulasi ini, mereka pun harus memahami apa yang menjadi penggerak sosial tantangan CSR, memiliki kemampuan untuk menyusun peraturan fungsional (misalnya, kode etik) dan mendorong perilaku yang bertanggung jawab bagi sosial dan lingkungan.

\section{Kedua, Kompetensi Personal atau Perilaku}

Kompetensi Personal atau Perilaku meliputi (a) Kemampuan untuk mengkomuni- kasikan isu keberlanjutan dalam kaitannya dengan masyarakat dan komunitas bisnis, (b) Mampu berpikir mandiri dan kemampu an riset atas permasalahan yang terjadi. Pentingnya kompetensi ini dimiliki akuntan seperti yang diungkapkan informan di bawah ini:

"Ada 12 keterampilan pokok Community Development Officer atau CDO. Keterampilan berkomunikasi, keterampilan bekerjasama dalam kelompok, Keterampilan mendidik, Keterampilan menyediakan Sumber Daya, Keterampilan menulis, Keterampilan memotivasi, Keterampilan persentasi, keterampilan bekerja dengan media, Keterampilan management, Keterampilan mengorganisir kegiatan, Keterampilan melakukan riset." (Ibu A)

Sebagai seorang CDO harus punya kreatifitas. Kita tidak perlu keahlian. Kita harus pintar, karena kalau masyarakat bertanya kita harus mampu menjawab. Harus mampu memberi solusi. (Ibu A)

Realitas ini mengungkap bahwa terdapat berbagai kecakapan yang harus dimiliki oleh akuntan jika ingin berkecimpung di dunia akuntansi sosial dan lingkungan. Posisi dan peran tim yang bertanggungjawab atas kegiatan CSR perusahaan juga menjadi ujung tombak perusahaan dalam menginformasikan strategi keberlanjutan yang dijalankannya kepada stakeholders. Misal dalam kegiatan sosialisasi program CSR maupun dalam penyusunan laporan keberlanjutannya, akuntan yang menjadi bagian tim ini semestinya memiliki kemampuan berkomunikasi dengan baik serta keterampilan dalam menentukan pilihan kata dan tampilan yang menarik dalam Sustainability Report agar apa yang diharapkan perusahaan dapat tersampaikan dengan baik kepada masyarakat.

Penelitian sebelumnya oleh BurkhardtHolm dan Chebbi, (2008); Osagie et al., (2016), kompetensi perilaku (disebut sebagai kompetensi interpersonal) ialah kemampuan mengelola program CSR yakni kemampuan untuk menerjemahkan strategi menjadi tindakan nyata. Kompetensi ini mencakup 
kemampuan untuk merencanakan, melaksanakan, juga mengelola proyek, keputusan, dan strategi yang mendukung CSR. Selain itu, profesional CSR harus bertanggung jawab kepada perusahaan dan masyarakat, mengembangkan dan menerapkan solusi untuk masalah praktis dan logis terkait CSR, bersikap persuasif, dapat mengidentifikasi kelompok pemangku kepentingan yang luas, memiliki kemampuan komunikasi dan networking yang baik (lokal dan global), bekerja dengan baik dalam kolaborasi multidisiplin dan multi-budaya, mengumpulkan dana, menulis laporan dan proposal terkait CSR, serta mampu mempresentasikan hasil kegiatan CSR.

\section{Ketiga, Kompetensi Pengetahuan atau Kognitif}

Suatu kesadaran akan permasalahan terkait regulasi dan keprihatinan profesi tentang isu keberlanjutan baik lokal maupun global. Harapan akan adanya kompetensi ini dalam diri akuntan digambarkan melalui ungkapan berikut:

"Peran accounting dalam proses CSR ini dimana, saya tidak tahu secara pasti. Bisa jadi kan kalo kita bicarakan auditing... apakah ini ada regulasi khusus pemerintah harus dikaitkan... kalau kita mengaudit program CSR gimana caranya... Menarik sebenarnya, karena CSR ini uang bebas, perlu accountable dalam process sampai reportingnya" (Bapak G) "Selain itu bagaimana hubungannya dengan taxationnya juga" (Bapak G)

Kesadaran informan dalam penelitian ini akan perkembangan yang pesat dalam bidang akuntansi sosial dan lingkungan memunculkan dimensi kompetensi baru yang dirasa penting untuk dimiliki para akuntan. Kemampuan untuk menangkap sinyal-sinyal perkembangan isu keberlanjutan teruatama terkait dengan kebijakan dan peraturan pihak-pihak ataupun lembaga yang berwenang menjadi hal yang tidak bisa dilewatkan. Seperti kondisi berikut ini, dimana beberapa tahun lalu dalam penyusunan laporan keberlanjutan perusahaan menggunakan GRI Guidance sebagai acuan mereka. Namun perkembangan berikutnya, GRI Standards menjadi acuan yang harus disadari dan dikuasai oleh akuntan sebab standar ini yang akan menggantikan GRI Guidance yang selama ini digunakan dan mulai diimplementasikan pada tahun 2018. Begitupun Osagie et al., (2016); dan Wiek et al., (2011), dalam hasil penelitian mereka menyebutkan bahwa kemampuan mengantisipasi perkembangan di masa depan dalam menghadapi tantangan CSR perlu dimiliki oleh seorang akuntan sosial dan lingkungan. Kemampuan ini seperti mampu menganalisis isu CSR terkait perilaku, konsep kunci, dan teori yang akan berkembang di masa depan. Kompetensi ini menuntut kemampuan berpikir kritis dan dapat mengantisipasi konsekuensi potensial dari tindakan organisasi dan individu.

\section{Keempat, Kompetensi Nilai atau Etika}

Kompetensi ini berupa pemikiran strategis tentang isu keberlanjutan mulai dari sudut pandang etika hingga isu-isu strategis mengenai kontribusi organisasi terhadap keberlanjutan kawasan lokal dan dunia. Senada dengan kebutuhan yang diutarakan informan berikut:

"Target akhir dari program kita ini adalah
bagaimana kemudian kita mampu secara
esensi membantu pemerintah.. komando
pemerintah ini ya... bagaimana secara
perlahan-lahan ekonomi di Kutai Timur
tidak bergantung pada tambang. Karena
kita tahu tambang akan habis. Soon or
later. Bisa karena habis, tambangnya ber-
henti beroperasi, entah karena habis, atau
karena sudah ndak ada yang mau beli,
harga sudah gak ekonomis, atau memang
karena gak diteruskan oleh pemerintah
kan kaya Freeport yang disuruh tutup."
(Ibu N)

Kompetensi ini menurut Osagie et al., (2016) merupakan hal mendasar bagi individu untuk melaksanakan CSR. Kemampuan untuk bersikap etis, empati, berkomitmen, antusias, kreatif, berpikir terbuka, fleksibel, sabar, gigih, dan pragmatis dalam pekerjaan 
mereka. Dengan demikian, mereka mampu untuk melakukan penyesuaian antara tujuan ekonomi perusahaan dan tujuan CSR tanpa kehilangan etika dan nilai moral. Kompetensi ini diwujudkan dalam kesesuaian antara apa yang diinginkan-dikatakan-dilakukan. Terkait keempat dimensi kompetensi tersebut, penelitian (Ng et al., 2017) menunjukkan bahwa peran utama pendidikan tinggi dalam bisnis adalah kepekaan terhadap dinamika perubahan yang sedang berlangsung dalam dunia bisnis. Ada keterampilan dan pengetahuan baru yang diharapkan dari generasi penerus akuntan profesional. Lulusan pendidikan akuntansi masa depan ini harus kompeten dalam pembuatan laporan, mampu bersikap etis, menyadari masalah peraturan terkait, serta mampu menganalisis dan menilai risiko keberlanjutan. Profesi akuntan masa depan ini akan membantu dalam melindungi dan meningkatkan akuntabilitas serta kinerja perusahaan terhadap keberlanjutan dunia. Secara spesifik, model kompetensi yang dihasilkan penelitan ini dengan mengadopsi model kompetensi keberlanjutan ( $\mathrm{Ng}$ et al., 2017) dapat dilihat pada gambar 3 berikut:

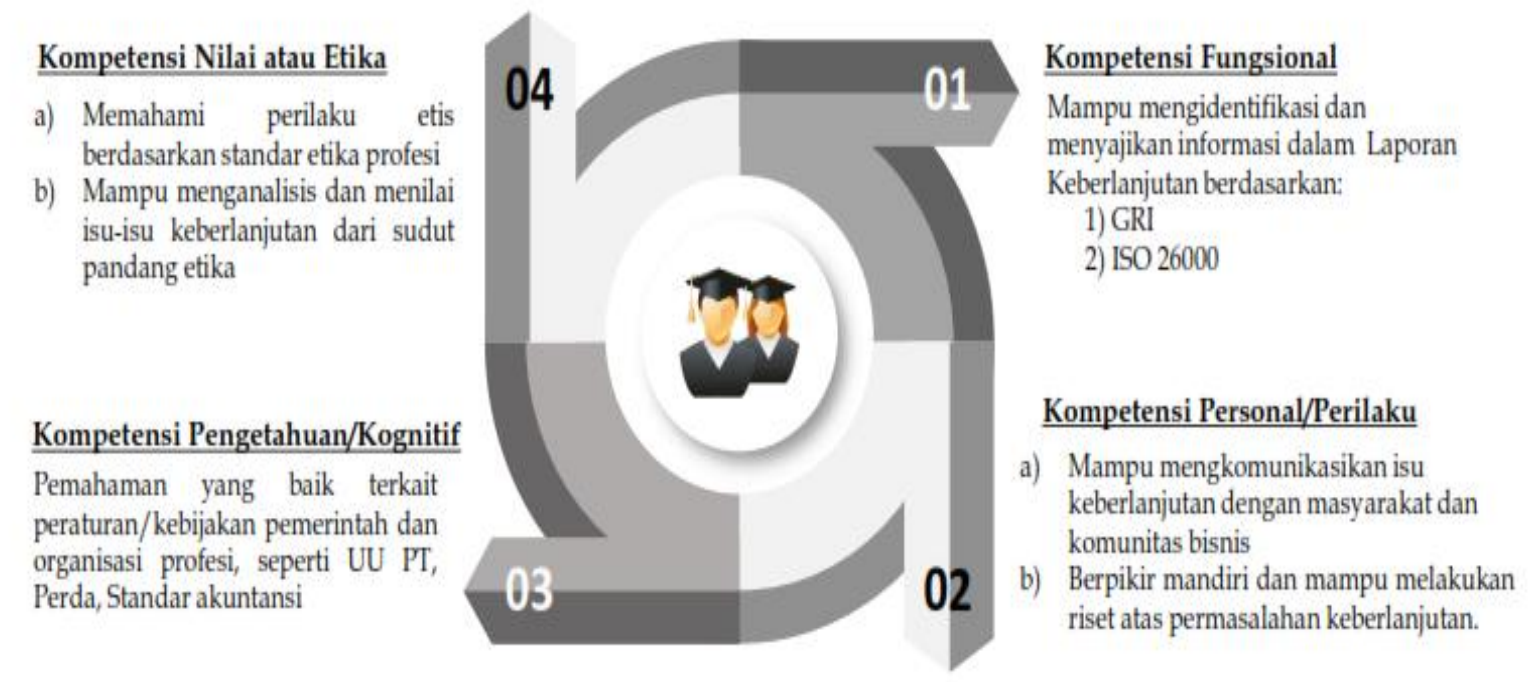

\section{Gambar 3 \\ Model Holistik Kompetensi Keberlanjutan (Pendidikan Akuntansi Sosial dan Lingkungan)}

Mekanisme dan pendekatan baru perguruan tinggi dalam mengajar dan melakukan penelitian dapat diimplementasikan dengan mendesain ulang kurikulum sesuai agenda keberlanjutan untuk pengembangan keterampilan, nilai, sikap dan kompetensi baru (Hazelton dan Haigh, 2010). Di samping itu, perguruan tinggi perlu melibatkan praktisi dan pemangku kepentingan di luar perguruan tinggi dalam mengenalkan "keberlanjutan", tidak hanya secara teoritis tetapi juga melalui tindakan praktis di kampus (Braun-Wanke, 2017; Chulián, 2011). Keterlibatan stakeholders Perguruan Tinggi akan menjembatani antara teori maupun praktik sehingga mahasiswa dapat memahami konsep CSR dengan baik, mampu menyusun dan menganalisis laporan keberlanjutan, serta kemampuan bersikap serta memiliki nilai-nilai yang sejalan dengan semangat 'keberlanjutan'.

\section{SIMPULAN DAN SARAN}

Akuntan sangat berperan dalam proses penyusunan dan pelaporan bisnis, mulai dari pelaporan keuangan hingga pelaporan non-keuangan seperti laporan keberlanjutan, dengan kompetensi demikian akuntan bisa 
mengukur dampak penerapan strategi keberlanjutan pada kinerja ekonomi, sosial dan lingkungan perusahaan dari tahun ke tahun. Secara global, tren dalam pengungkapan dan pelaporan keberlanjutan memberikan dorongan untuk mendidik mahasiswa akuntansi dalam masalah akuntansi sosial dan lingkungan. Peningkatan permintaan akan pelaporan keberlanjutan maka pendidikan akuntansi keberlanjutan akan menjadi hal yang relevan di perguruan tinggi. Lulusan perguruan tinggi di bidang akuntansi memerlukan meta-kompetensi keberlanjutan yakni kompetensi fungsional, kompetensi personal/perilaku, kompetensi pengetahuan/kognitif, dan kompetensi nilai/etika. Kompetensi fungsional difokuskan pada perlunya para calon akuntan memiliki pemahaman yang memadai terkait standar atau acuan dalam implementasi dan pelaporan akuntansi keberlanjutan, diantaranya memahami tentang yang diatur dalam ISO 26000 dan GRI. Kompetensi berikutnya adalah personal/perilaku yang menunjukkan tentang kemampuan akuntan untuk mengkomunikasikan program keberlanjutan perusahaan kepada masyarakat dan mampu memberikan pemecahan masalah dengan riset atas isu keberlanjutan tersebut. Ketiga adalah kemampuan kognitif yang menghendaki adanya pemahaman yang memadai tentang lingkungan atau boundaries ketika perusahaan beroperasi terutama berhubungan dengan aturan-aturan dan perundangundangan pemerintah setempat atau lembaga lain yang patut diatuhi perusahaan. Kemudian diperlukan juga kompetensi nilai/etika mengenai bagaimana pemahaman dan kemampuan analisis dari akuntan atas nilai dan perilaku etis berkaitan dengan isu keberlanjutan. Keempatnya disebut model holistik kompetensi profesional dimana lulusan akan siap untuk menjadi akuntan sosial dan lingkungan yang membantu perusahaan meningkatkan akuntabilitas dan kinerja perusahaan.

Perguruan Tinggi khususnya program studi akuntansi perlu untuk segera melakukan peninjauan kurikulum sarjana akuntansi dengan menambahkan atribut kompetensi akuntansi sosial dan lingkungan sehingga lulusan memiliki penguasaan dalam pengetahuan dan pemahaman akuntansi sosial dan lingkungan, ketrampilan dalam praktik pelaporan keberlanjutan, dan mampu bersikap etis serta profesional.

\section{DAFTAR PUSTAKA}

Adams, C. A., M. G. Heijltjes, G. Jack, T. Marjoribanks, dan M. Powell. 2011. The Development of Leaders Able to Respond to Climate Change and Sustainability Challenges: The Role of Business Schools. Sustainability Accounting, Management and Policy Journal 2(1): 165-171.

Ascui, F. dan H. Lovell. 2012. Carbon Accounting and the Construction of Competence. Journal of Cleaner Production 36: 48-59.

Astuti, N. 2012. Mengenal Green Accounting. PERMANA IV(1): 69-75.

Astuti, W. 2009. Akuntansi dan Akuntan dalam Kacamata Posmodernisme. Jurnal Riset Akuntansi dan Bisnis 9(1): 17-42.

Banerjee, S. B. 2004. Teaching Sustainability: a Critical Perspective. Theaching Business Sustainability: 34-47.

Braun-Wanke, K. 2017. Learning and Teaching for a Sustainable Future. Handbook of Theory and Practice of Sustainable Development in Higher Education 4: 15-29.

Burkhardt-Holm, P. dan C. Chebbi. 2008. Master's Degree in Sustainable Development in Switzerland, the First Master Course Comprising Three Facul- ties. Environmental Science and Pollution Research 15(2): 136-142.

Çalıskan, A. Ö. 2014. How Accounting and Accountants May Contribute in Sustainability?. Social Responsibility Journal 10(2): 246-267.

Chaker, M. N. dan T. A. T. Abdullah. 2011. What Accountancy Skills are Acquired at College?. International Journal of Business and Social Science 2(18): 193-199.

Christensen, L. J., E. Peirce, L. P. Hartman, W. M. Hoffman, dan J. Carrier. 2007. Ethics, CSR, and Sustainability Edu- 
cation in the Financial Times Top 50 Global Business Schools: Baseline Data and Future Research Directions. Journal of Business Ethics 73(4):347-368.

Chulián, M. F. 2011. Constructing New Accountants: The Role of Sustainability Education. Revista de Contabilidad-Spanish Accounting Review 14(1): 241-265.

Cooper, C. 1992. The Non and Nom of Accounting for (M) other Nature. Accounting, Auditing \& Accountability Journal 5(3): 16-39.

Dahle, M. dan E. Neumayer. 2001. Overcoming Barriers to Campus Greening: a Survey among Higher Educational Institutions in London, UK. International Journal of Sustainability in Higher Education 2(2): 139-160.

Hazelton, J. dan M. Haigh. 2010. Incorporating Sustainability into Accounting Curricula: Lessons Learnt from an Action to Research Study. Accounting Education: An International Journal 19(12): 159-178.

Humphrey, C., B. O’Dwyer, dan J. Unerman. 2017. Re-theorizing the Configuration of Organizational Fields: the IIRC and the Pursuit of 'Enlightened' Corporate Reporting. Accounting and Business Research 47(1): 30-63.

Jankalova, M. 2016. Approaches to the Evaluation of Corporate Social Responsibility. Procedia Economics and Finance 39(2016): 580-587.

Januarti, I. dan D. Apriyanti. 2005. Pengaruh Tanggung Jawab Sosial Perusahaan terhadap Kinerja Keuangan. MAKSI 5(2): 227-253.

Kaya, I. 2016. The Mandatory Social and Environmental Reporting: Evidence from France. Procedia - Social and Behavioral Sciences 229(2016): 206-213.

Kettunen, J. 2015. Stakeholder Relationships in Higher Education. Tertiary Education and Management 21(1): 56-65.

Kuncoro, M. dan A. N. Idris. 2010. Mengapa Terjadi Growth Without Development di Provinsi Kalimantan Timur?. Jurnal Ekonomi Pembangunan 11(2): 172-190.
Kusumaningtias, R. 2013. Green Accounting, Mengapa dan Bagaimana?. Proceeding Seminar Nasional Dan Call for Papers Sancall Surakarta: 137-149.

Kusumawardani, A., Irwansyah, L. Setyawati, dan Y. L. Ginting. 2017. Urgensi Akuntan Sosial dan Lingkungan: Perspektif Institusional. Proceedings Profesionalisme Akuntan Menuju Sustainable Business Practice. Bandung: 939-948.

Lange, D. E. de. 2013. How do Universities Make Progress? Stakeholder-Related Mechanisms Affecting Adoption of Sustainability in University Curricula. Journal of Business Ethics 118(1): 103-116.

Mainardes, E. W., H. Alves, dan M. Raposo. 2010. An Exploratory Research on the Stakeholders of a University. Journal of Management and Strategy 1(1): 76-88.

Manoliadis, O. 2009. Education For Sustainability: Experiences From Greece. Journal of Professional Issues in Engineering Education and Practice 135(2): 70-74.

Mathews, R. dan C. Sturt. 2002. Reflections on Social and Environmental Accounting Education. Journal of the Asia Pasific Centre for Environmental Accountability 8(4): 335-352.

Milne, M. J. 2001. Commentary on: Some Thoughts on Social and Enironmental Accounting Education. Accounting Education 10(4): 335-352.

Mulyati, H. 2012. Kemampuan Dasar-Dasar Akuntansi dan Keberlanjutan Studi di Program Studi Akuntansi di Lingkungan Perguruan Tinggi Muhammadiyah (PTM) Jakarta. Jurnal Liquidity 1(1): 1-12.

Ng, A. W., T. C. H. Leung, dan J. M. K. Lo. 2017. Developing Sustainability Competence for Future Professional Accountants: The Integrative Role of an Undergraduate Program. Handbook of Theory and Practice and Sustainable Development in Higher Education 1: 119-136. Springer. Switzerland.

O'Byrne, D., W. Dripps, dan K. A. Nicholas. 2015. Teaching and Learning Sustainability: An Assessment of the Curri- 
culum Content and Structure of Sustainability Degree Programs in Higher Education. Sustainability Science 10(1): 43-59.

Osagie, E. R., R. Wesselink, V. Blok, T. Lans, dan M. Mulder. 2016. Individual Competencies for Corporate Social Responsibility: a Literature and Practice Perspective. Journal of Business Ethics 135(2): 233-252.

Peraturan Daerah Provinsi Kalimantan Timur Nomor 3 Tahun 2013 tentang Tanggung Jawab Sosial dan Lingkungan Perseroan Terbatas.

Polejewski, S. 2011. Sustainability Accounting and Reporting. Accounting Instructor's Report2, Summer.

Pratama, A. 2015. Bridging the Gap between Academicians and Practitioners on Accountant Competencies: An Analysis of International Education Standards (IES) Implementation on Indonesia's Accounting Education. Procedia - Social and Behavioral Sciences 211: 19-26.

Pratiwi, M. C. Y. dan M. Kuncoro. 2016. Analisis Pusat Pertumbuhan dan Autokorelasi Spasial di Kalimantan: Studi Empiris di 55 Kabupaten/Kota, 20002012. Jurnal Ekonomi dan Pembangunan Indonesia 16(2): 81-104.

Rajafi, L. R., dan G. Irianto. 2007. Akuntansi Pertanggungjawaban Sosial Perusahaan (Studi pada Bursa Efek Jakarta). Tema 8(1):56-75.

Rassart, C. 2014. Sustainability: Gain a Competitive Advantage. https://www2. deloitte.com/ca/en/pages/energy-and-resour ces/articles/sustainability-performance. html. Diakses tanggal 12 Oktober 2017.

Sanchez, M. H. 2015. Introducing the Concepts of Sustainability and Corporate Social Responsibility to Accounting Students. Business Education and Accreditation 7(2): 69-73.

Santoso, H. F. 2012. Akuntansi Lingkungan Tinjauan terhadap Sistem Informasi Akuntansi Manajemen atas Biaya Lingkungan. Jurnal Akuntansi 12(2): 635-654.
Sharma, R. 2017. Enhancing Sustainability Awareness through Social Learning Experiences on Campuses. International Journal of Educational and Pedagogical Sciences 11(11): 2427-2430.

Sihombing, R. 2015. The Indonesia Best Sustainability Report as a Student's Accounting Tool to Understand CSR Concept. Jurnal Dinamika Akuntansi 7(1): 161-166.

Solihin, I. 2009. Corporate Social Responsibility. Salemba Empat. Jakarta.

Stephens, J. C., M. E. Hernandez, M. Román, A. C. Graham, dan R. W. Scholz. 2008. Higher Education as a Change Agent for Sustainability in Different Cultures and Contexts. International Journal of Sustainability in Higher Education 9(3): 317-338.

Sugiyono. 2006. Metode Penelitian Pendidikan (Pendekatan Kuantitatif, Kualitatif dan $R \mathcal{E D}$. Alfabeta. Bandung.

Undang-Undang Republik Indonesia Nomor 40 Tahun 2007 tentang Perseroan Terbatas.

Wiek, A., L. Withycombe, C. Redman, dan S. B. Mills. 2011. Moving Forward on Competence in Sustainability Research and Problem Solving. Environment: Science and Policy Sustainable Development 53(2): 3-13.

Wong, J., S. Pippin, J. Weber, dan J. Bergner. 2016. The Inclusion of Sustainability in the Accounting Curriculum. The CPA Journal 86(6): 44-47.

Wymer, W. dan S. R. Rundle-Thiele. 2017. Inclusion of Ethics, Social Responsibility, and Sustainability in Business School Curricula: a Benchmark Study. International Review on Public and Nonprofit Marketing 14(1): 19-34.

Yarime, M., G. Trencher, T. Mino, R. W. Scholz, L. Olsson, B. Ness, N. Frantzeskaki, dan J. Rotmans. 2012. Establishing Sustainability Science in Higher Education Institutions: Towards an Integration of Academic Develop- ment, Institutionalization, and Stake holder Collaborations. Sustainability Science 7(1): 101-113. 